\title{
CONGENITAL CYTOMEGALOVIRUS INFECTION. OCCURRENCE IN TWO SOCIOECONOMICALLY DISTINCT POPULATIONS OF A DEVELOPING COUNTRY
}

\author{
Claudio S. PanNuti (1,2), Lucy S. Vilas.boas (1), Marla J. O. ANGelo (1), Renato
}

P. S. CARvalho (1) and Concelģäo M. SEGRE $(2,3)$

\begin{abstract}
$\mathbf{S} \mathbf{U} \mathbf{M} \mathbf{M} \mathbf{R} \mathbf{Y}$
In São Paulo, Brazil, between November 1980 and July 1982, 1614 newborns of middle socioeconomic background and 1156 newborns of low socioeconomic background were examined for the occurrence of congenital cytomegalovirus (CMV) infection by isolation of virus from urine samples or detection of specific anti-CMV IgM in umbilical cord serum tested by immunofluorescence. In the low socioeconomic population prevalence of $\mathrm{CMV}$ complement-fixing antibodies in mothers was $84.4 \%(151 / 179)$ and the incidence of congenital infection assessed by virus isolation $0.98 \%(5 / 508)$, as compared with $0.46 \%(3 / 648)$ in the group of newborns tested by detection of specific anti-CMV IgM in umbilical cord-serum. In middle socioeconomic level population prevalence of $\mathrm{CMV}$ complement-fixing antibodies in mothers was $66.5 \%(284 / 427)$ and the incidence of CMV congenital infection was $0.39 \%(2 / 518)$ in the group of newborns screened by virus isolation and $0.18 \%(2 / 1096)$ in the group tested by detection of specific anti-CMV IgM. In the present study none of the 12 congenitally infected newborns presented clinical apparent disease at birth.
\end{abstract}

\section{N T R O D U C T I O N}

In developed countries, cytomegalovirus (CMV) is the most common cause of congenital infections, with incidences ranging between 0.24 and $2.2 \%$ of all live births ${ }^{4}$.

Previous reports indicated that the incidence of congenital CMV infection in a given population is inversely related to the rate of susceptibility to primary infection in women of childbearing age. However, these studies are scant and limited to the state of Alabama, USA 2.5 .

The purpose of the present study was to determine the incidence of congenital CMV infection in two socioeconomically distinct popu- lations living in the same geographic area of a developing country.

\section{MATERIAL AND METHODS}

Between November 1980 and July 1982, 1614 newborns from middle socioeconomic background (from Hospital do Servidor Público Estadual de São Paulo) and 1156 newborns from low socioeconomic background (from Hospital Maternidade Escola Vila Nova Cachoeirinha) were examined for the occurrence of congenital cytomegalovirus infection.

The socioeconomic background of the two groups was evaluated through an interview

(1) Instituto de Medicina Tropical de São Paulo, Săo Paujo, Brandl

(2) Hospital do Servidor Público Estadual de Sāo Paulo, Såo Paulo, Brazll

(3) Hospital Maternidade Escola Vila Nova Cachoefrinha, Sāo Paulo, Brazil

Please address request for reprints to: Claudio S. Pannuti, M.D. Instituto de Medicina Troplcal de Sto Paulo. Av. Dr. Enéias de Carvalho Aguiar, 470, 05403 Sāo Paulo, Brazil 
PANNUTI, C. S.; VILAS-BOAS, L. S.; ANGELO, M. J. O.; CARVALHO, R. P. S. \& SEGRE, C. M. - Congenital cytomogalovirus infection. Occurrence in two socioeconomically distinct populations of a developing country. Rev. Inst. Med. trop. São Paulo 27:105-107, 1985.

schedule developed by BELIZAN et al., from PAHO ${ }^{1}$, in which the age, occupation and educational level of the pregnant women (and their husbands) were determined, as well as the prevalence of newborns with low birth weight and multiparity.

Of the 1614 middle socioeconomic level newborns, 518 were examined by isolation of virus from urine samples, collected within the first seven days of life and processed by inoculation onto monolayers of fibroblasts derived from human foreskin ${ }^{3}$. The other 1096 were examined exclusively by detection of specific immunofluorescent anti-CMV IgM in umbilical-cord serum ${ }^{3}$. Of the 1156 low socioeconomic level newborns 508 were examined by virus isolation and 648 by specific immunofluorescent IgM assay. The maternal immune status at delivery was defined by means of a complement fixation test, using as antigen Ad 169 (Behringwerke A.G.).

Student's t-test and chi square test were used to determine statistical significance.

\section{RESULTS AND DISGUSSION}

The pregnant women of low socioeconomic level group were younger (mean age 25,49 $x$
28,58, $p<0.0001$ ) and differed significantly from those in the median socioeconomic level group in all the aspects assessed by the interview schedule.

The proportion of congenital CMV infection in low and middle socioeconomic level populations assessed by virus isolation and by detection of specific anti-CMV in umbilical-cord serum can be seen in Table I. Our results, in a developing country, seem to agree with previous reports that showed differences in congenital CMV infection incidences related to the socioeconomic background of the populations studied 2.5 . Thus, in our study the occurrence of congenital CMV infection was 2.5 times higher in the highly immune-low socioeconomic level population when compared with the middle socioeconomic level. Nevertheless, this difference was not statistically significant $(0.20<$ $\mathrm{p}<0.30$ ), irrespective of using virus isolation or detection of anti.CMV specific IgM anti. bodies in umbilical cord serum as the diagnostic tool.

The proportion of primary CMV infection during pregnancy is thought to be very similar in serosusceptible women of different socio-

T A B L E I

Congenital cytomegalovirus infection and maternal immune status according to socloeconomic level

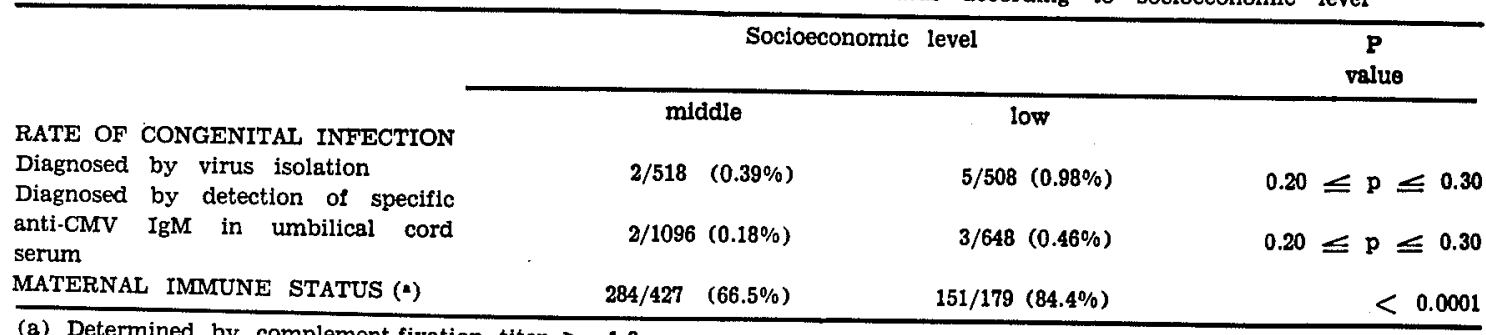

(a) Determined by complement-fixation titer $\supseteq 1: 8$

economic background 5 . As the prevalence of seronegative mothers in the low socioeconomic level group $(15.6 \%)$ was significantly lower than the prevalence observed in the middle socioeconomic level group $(33.5 \%)$ ( $p<0.001)$, our finding of a 2.5 times higher incidence of congenital infection in the low income population provide indirect evidence that, in our series, reactivation was the cause of most of CMV congenital infections.

Incidence of CMV congenital infection was about $50 \%$ lower in the group of newborn test- ed exclusively by umbilical cord FA-IgM when compared with the group tested by virus iso. lation.

In the present study none of the 12 congenitally infected newborns presente clinically apparent disease at birth.

\section{RESUMO}

Infecção congênita pelo citomegalovírus. Ocorrência em duas populações de nivel sócio-econômico diferentes em São Paulo, Brasil 
PANNUTI, C. S.; VIllas-BOAS, L. S.; ANGELO, M. J. O.; CARValho, R. P. S. \& SEGRE, C. M. - Congenital cytomegalovirus infection. Occurrence in two socioeconomically distinct populations of a developing country. Rev. Inst. Med. trop. São Paulo 27:105-107, 1985.

Entre novembro de 1980 e julho de 1982, 1614 recém-nascidos (RNs) de nivel sócio-econômico médio e 1156 RNs de baixo nivel sócioeconômico foram examinados para verificar a ocorrência de infecção congênita pelo citomegalovírus (CMV), através de isolamento do vírus em amostras de urina ou detecção de anticorpos IgM específicos em amostras de sangue de cordão umbilical. Na população de baixo nível sócio econômico a prevalência de anticorpos fixadores do complemento (Ac Fc) antiCMV nas mães foi de $84,4 \%(151 / 179)$ e a in cidência de infecção congênita determinada por isolamento do vírus foi de $0,90 \%(5 / 508)$. No grupo de RNs em que o diagnóstico baseou-se apenas na deteç̧ão de Ac IgM CMV-especifi$\cos$ no sangue de cordão a incidência de infecção congênita foi de apenas $0,46 \%(3 / 648)$.

Na população de nível sócio-econômico médio a prevalência de Ac Fc anti-CMV nas mães foi de $66,5 \%(284 / 427)$ e a incidência de infecção congênita foi de $0,39 \%(2 / 518)$ no grupo de RNs testados por isolamento de vírus na urina e $0,18 \%(2 / 1090)$ no grupo testado por detecção de Ac IgM especificos.

No presente estudo nenhum dos 12 RNs infectados congenitamente apresentou sinais ou sintomas de doença ao nascimento.

\section{ACKNOWLEDGMENTS}

We are indebted to Dr. José Maria Pacheco de Souza and Miss Angela Ledesma for statistical analysis.

The cooperation of the medical, nursing and administrative staff of the neonatal units at Hospital do Servidor Público Estadual de São Paulo and Hospital Maternidade Escola Vila Nova Cachoeirinha is greatly appreciated.

This study was supported by funds from the "Laboratórios de Investigação Médica do Hospital das Clinicas da Faculdade de Medicina da Universidade de São Paulo".

\section{REFERENCES}

1. BELIZAN, J. M.; DIAZ, A. G.; GIACOMINI, H.; HORCHER, R.; MARTELL, M.; QUARANTA, P. \& SCH WARCZ, R. - Historia clinica perinatal. Propuesta de un modelo. Buenos Aires, Centro Latinoamericano de Administración Médica, 1976.

2. MONTGOMERY, J. R.; MASON Jr., E. O.; WILLTAMSON, A. P. ; DESMOND, M. M. \& SOUTH, M. A. Prospective study of congenital cytomegalovirus infection. Sth. med. J. (Bgham, Ala) 73: 590-593, 1980.

3. REYNOLDS, D. W.; STAGNO, S. \& ALFORD, C. A. Laboratory diagnosis of cytomegalovirus infections. In E. H. Lennette \& N. J. Schmidt ed). Diagnostic Procedures for Viral, Rickettsial and Chlamydial Infections. 5th ed. Washington, American Public Health Association, 1979, 399.439.

4. STAGNO, S.; PASS, R. F.; DWORSKY, M. E. \& ALFORD Jr., C. A. - Maternal cytomegalovirus infection and perinatal transmission. Clin. Obstet. Gynec. 25: 563.576, 1982 .

5. STAGNO, S.; PASS, R. F.; DWORSKY, M. E.; HEN DERSON, R. E.; MOORE, E. G.; WALTON, P. D. \& ALFORD Jr., C. A. - Congenital cytomegalovirus infection. The relative importance of primary and recurrent maternal infection. New Engl. J. Med. 306: 945. 949, 1982.

Recebido para publicação em 17/9/1984. 